\title{
Systematic literature review assessing tobacco smoke exposure as a risk factor for serious respiratory syncytial virus disease among infants and young children
}

\author{
Joseph R DiFranza ${ }^{*}$, Anthony Masaquel ${ }^{2}$, Amy M Barrett ${ }^{3}$, Ann D Colosia $^{3}$ and Parthiv J Mahadevia²
}

\begin{abstract}
Background: The role of environmental tobacco smoke (ETS) exposure as a risk factor for serious respiratory syncytial virus (RSV) disease among infants and young children has not been clearly established. This systematic review was conducted to explore the association between ETS exposure and serious RSV disease in children younger than 5 years, including infants and young children with elevated risk for serious RSV disease.
\end{abstract}

Methods: A systematic review of English-language studies using the PubMed and EMBASE databases (1990-2009) was performed to retrieve studies that evaluated ETS as a potential risk factor for serious RSV illness. Studies assessing risk factors associated with hospitalization, emergency department visit, or physician visit due to RSV (based on laboratory confirmation of RSV or clinical diagnosis of RSV) in children under the age of 5 years were included.

Results: The literature search identified 30 relevant articles, categorized by laboratory confirmation of RSV infection $(n=14)$, clinical diagnosis of RSV disease $(n=8)$, and assessment of RSV disease severity $(n=8)$. Across these three categories of studies, at least 1 type of ETS exposure was associated with statistically significant increases in risk in multivariate or bivariate analysis, as follows: 12 of 14 studies on risk of hospitalization or ED visit for laboratoryconfirmed RSV infection; 6 of 8 studies of RSV disease based on clinical diagnosis; and 5 of the 8 studies assessing severity of RSV as shown by hospitalization rates or degree of hypoxia. Also, 7 of the 30 studies focused on populations of premature infants, and the majority (5 studies) found a significant association between ETS exposure and RSV risk in the multivariate or bivariate analyses.

Conclusion: We found ample evidence that ETS exposure places infants and young children at increased risk of hospitalization for RSV-attributable lower respiratory tract infection and increases the severity of illness among hospitalized children. Additional evidence is needed regarding the association of ETS exposure and outpatient RSV lower respiratory tract illness. Challenges and potential pitfalls of assessing ETS exposure in children are discussed.

Keywords: Respiratory syncytial virus, Respiratory infection, Tobacco, Smoking, Children

\footnotetext{
*Correspondence: DiFranza@umassmemorial.org

'Department of Family Medicine and Community Health, University of Massachusetts Medical School, 55 Lake Avenue North, Worcester, MA 01655, USA

Full list of author information is available at the end of the article
} 


\section{Background}

Almost all children contract respiratory syncytial virus (RSV) by 2 years of age [1]. RSV causes upper airway infections, bronchiolitis, wheezy bronchitis, and pneumonia. Although most infections produce mild disease, RSV is a major cause of hospitalization in infants [2] and can be fatal [3]. Premature infants, infants with bronchopulmonary dysplasia (BPD) (chronic lung disease of prematurity), and infants with congenital heart disease are at risk for serious infections [4,5]. Risk factors for RSV infection include exclusive bottle feeding $[6,7]$, having older brothers or sisters in the household $[6,8,9]$, male gender $[10]$, low birth weight $[10,11]$, prematurity [6], household crowding [12], and young chronologic age [9]. Although exposure to environmental tobacco smoke (ETS) is a risk factor for asthma, wheezing, decreased pulmonary function, otitis media, cough, and lower respiratory tract infections (LRTIs) in general [13], its role in the development of serious RSV disease among infants and young children is less clear and has been a topic of interest among the healthcare community [14].

In this systematic review, we evaluated the evidence of an association between ETS exposure and serious RSV disease among children younger than 5 years. To obtain the broadest understanding of whether ETS exposure affects the risk of serious RSV disease, we placed no limits on the type of proxy measures of ETS exposure. Understanding the evidence basis for ETS exposure and RSV could highlight the need to direct healthcare resources or intervention programs toward this potentially modifiable risk factor.

\section{Methods}

\section{Patient population}

In this systematic literature review, we included studies of infants and children up to 5 years of age, including studies of children at high risk for serious RSV disease. We defined the high-risk population as patients with prematurity, BPD, or congenital heart disease. All other patient populations were defined as general populations, which consisted predominantly of children not defined as high risk.

\section{Search strategy}

Following PRISMA guidelines, we conducted a systematic review of the association of ETS exposure with serious RSV disease by searching broadly for studies assessing various risk factors, including ETS exposure, for RSV, bronchiolitis, or LRTI caused by RSV or bronchiolitis.[15] We searched the PubMed (including MEDLINE) and EMBASE databases for English-language studies published and indexed between 1990 and April 2009. No additional relevant unpublished studies were obtained. Studies that identified ETS exposure as a risk factor might be more likely to mention ETS in the title or abstract than studies that evaluated ETS exposure in a set of other risk factors, but did not find it to be significantly associated with increased risk. To minimize article selection bias across studies, we searched for articles that assessed any risk factors for RSV as well as bronchiolitis, because $50 \%$ to $80 \%$ of winter bronchiolitis is due to RSV in infants and young children [1]. For PubMed, the National Library of Medicine Medical Subject Headings (MeSH terms) used in the search included tobacco smoke pollution/adverse effects, respiratory syncytial virus infections, bronchiolitis viral, and respiratory tract infections in combination with the MeSH subheadings epidemiology, etiology, and complications. The $\mathrm{MeSH}$ heading respiratory tract infections was combined with the keywords syncytial or RSV OR bronchiolitis or the MESH term tobacco smoke pollution/adverse effects. Studies that included risk assessment were identified using the following MeSH headings: analysis of variance (which includes multivariate analysis), probability (which includes proportional hazards model, odds ratio, risk, risk assessment, and risk factors); and case-control studies or cohort studies, which were combined with the terms relative risk OR hazard ratio OR odds ratio. The search identified studies with the following combination of these terms: (1) any disease-related term plus any risk assessment term; or (2) any disease-related term plus the smoke exposure term. We did not search for unpublished studies or reports.

\section{Study selection}

Each relevant article was read by several authors and the bibliographies of included articles were reviewed for additional studies. We excluded studies that did not assess disease risk or did not include ETS exposure as a risk factor. Figure 1 presents a summary of exclusions and rationales for exclusion during successive rounds of review.

\section{Data extraction}

Study details were extracted into tables, and table content was verified by a second author and by a reviewer not involved in the data extraction. The authors discussed each article to reach consensus regarding the study details. For each study the following data were extracted: reference, publication year, country origin, study design, study population size and description, assessment method for ETS exposure (e.g., maternal smoking through birth certificate data), method of ascertainment of RSV status (if any, such as through laboratory confirmation or clinical diagnosis), disease outcome evaluated (e.g., hospitalization for RSV), and results and significance of multivariate, bivariate, and other statistical analyses. Outcomes related 


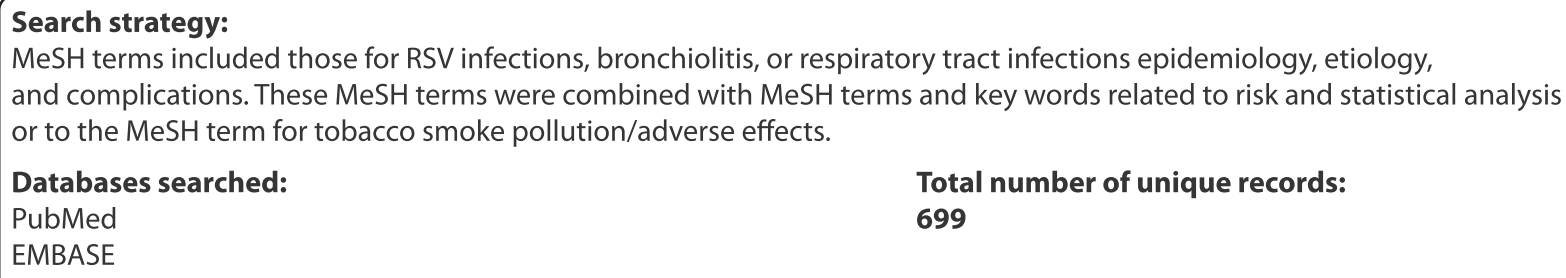

Figure 1 PRISMA Flow Diagram: Summary of Exclusions and Rationales for Exclusion During Phases of Systematic Literature Review. PRISMA = Preferred Reporting Items for Systematic Reviews and Meta-Analyses; LRTI = lower respiratory tract infection; MeSH = medical subject headings; RSV = respiratory syncytial virus.

to the presence of RSV antibodies without evidence of hospitalization, ED visit, or physician visit related to RSV were not extracted. The principal summary measures were adjusted odds ratios (aORs), adjusted rate ratios (aRRs), or adjusted hazard ratios (aHRs) for multivariate analyses and odds ratios (ORs) for bivariate analyses. Several studies that did not perform multivariate analyses performed between-group comparisons and presented $P$ values.

\section{Assessment of risk of bias}

Among the studies meeting the inclusion criteria, we evaluated the risk of bias at the outcome and study level using the Cochrane risk of bias tool [16]. The Cochrane risk of bias tool was developed primarily for use in interventional studies; we used the tool to examine factors specific to sources of bias frequently found in observational studies. The studies were examined for risk of bias that would potentially influence the association of ETS exposure with serious RSV disease. The studies were judged regarding evidence of misclassification bias of RSV disease, selective reporting bias, confounding bias, exposure ascertainment bias, or participant selection bias. Disease misclassification bias was assessed based on the likelihood of the study population having an LRTI that was not due to RSV. We expect that disease misclassification would underestimate the association 
between ETS exposure and serious RSV disease. Selective reporting bias was evaluated based on whether outcomes related to risk factors were clearly reported. Confounding bias was assessed based on whether the study controlled for the effects of other variables through multivariate analysis. We expect that unadjusted results may overestimate the association between ETS exposure and serious RSV disease. Exposure ascertainment bias was assessed based on whether the ETS exposure variables were described clearly and determined by the study authors to be adequate measures of ETS exposure in the study population. Finally, participant selection bias was pointed out in case-control studies in which the control group consisted of ill patients with non-RSV respiratory disease, and therefore, the effect of ETS exposure on serious RSV disease could be biased toward the null.

\section{Results}

The search of PubMed and EMBASE databases yielded 699 unique results, and the abstracts were reviewed for relevance (Figure 1). Of these, 676 were excluded through successive rounds of review, the majority because the studies did not focus on a disease of interest (RSV, bronchiolitis, or LRTI attributable to RSV or bronchiolitis), were not conducted in a population of interest (children younger than 5 years without serious nonrespiratory disease, such as cancer or organ transplant), or did not assess ETS exposure.

Full review of 57 articles resulted in the exclusion of 34 articles, leaving 23 articles identified by the electronic search. The addition of 7 articles identified from references cited (4 were published before 1990) produced a total of 30 relevant articles.

\section{Overview of studies}

The results are organized by study characteristics and include a bias assessment summary for each study. (The full bias assessment is presented in Additional file 1: Table S1) Table 1 presents 14 studies that established a diagnosis of RSV disease by confirmatory laboratory testing. These studies compared children with RSV infections with children without respiratory illness and assessed whether ETS exposure increased the risk for developing a serious RSV infection. Table 2 presents 8 studies that did not confirm suspected cases of RSV disease with laboratory testing, but relied on the clinical diagnosis of RSV or bronchiolitis, often from medical charts or insurance data. These studies also compared children with RSV or bronchiolitis infections with children without respiratory illness. Table 3 presents 8 studies that examined the impact of ETS exposure on the severity of RSV disease as measured by hospitalization or degree of hypoxia. These studies started with a sample of children infected with RSV and assessed whether ETS exposure increased the severity of the RSV infection. Within each group of studies, we considered studies of premature infants separately because this population is at higher risk for serious RSV disease than the general population of children $[17,18]$. We also present the results by study design (e.g., cohort, casecontrol) in each table.

The methods used to assess ETS exposure status varied widely and included mother's prenatal smoking status, mother's postnatal smoking status, father's smoking status, smoking in the home, number of smokers in the household, number of cigarettes smoked in the home, more than five cigarettes smoked per day in the home, days of smoke exposure, history of exposure to smoking, smoking by daycare provider, and cotinine levels.

Some of the studies summarized included more than one source of ETS exposure, but no study detailed missing ETS exposure status data. In the studies reporting multiple ETS exposure, we have presented all results based on the different sources (e.g., maternal smoking during pregnancy and smokers in the household) because it is difficult to determine in each setting which of several proxies for total ETS exposure results in the least misclassification error. Few of the multivariate studies provided a rationale for their selection of control variables. We therefore included positive bivariate results in our tables when bivariate and multivariate analyses produced disparate conclusions.

\section{ETS exposure and laboratory-confirmed RSV disease}

The studies in Table 1 seek to answer the question, does ETS exposure increase the risk that an uninfected child will develop serious RSV? In 14 studies, the diagnosis of RSV infection was confirmed by laboratory testing (Table 1). Of these, 12 studies showed a significant adverse impact of ETS exposure on serious RSV in bivariate or multivariate analysis as measured by at least one exposure variable. These studies examined the association of ETS exposure and other factors on the risk of ED visit [23] or hospital admission [5,6,9,10,12,19-21,24-26] for laboratory-confirmed RSV LRTI. Two studies examining laboratory-confirmed RSV did not find a statistically significant association between ETS exposure and serious RSV: a cohort study of outpatients in the United States assessing the risk of a child presenting to the pediatrician's office with an RSV infection [22], and an Australian case-control study assessing the risk of RSV hospitalization [11].

Four of these 14 studies contained at least one significant association, but found mixed results with different ETS exposure variables $[6,19,20,23]$. One prospective cohort study in premature infants found that maternal smoking and parental smoking in the home had 
Table 1 Studies Reporting Risk of Developing Serious RSV (Laboratory-Confirmed RSV; $\mathbf{N}=14$ )

\begin{tabular}{|c|c|c|c|c|c|}
\hline Study, Year, Country & Design and Population & ETS Exposure & Outcome & Results & Bias Assessment/Comment \\
\hline \multicolumn{6}{|c|}{ Prospective cohort studies in premature infants } \\
\hline \multirow[t]{6}{*}{$\begin{array}{l}\text { Broughton } 2005 \text { United } \\
\text { Kingdom [19] }\end{array}$} & \multirow{6}{*}{$\begin{array}{l}\text { Prospective study of } \\
126 \text { premature infants } \\
\text { (GA }<32 \text { wks; } 40 \% \\
\text { developed BPD) }\end{array}$} & $\begin{array}{l}\text { Maternal smoking } \\
\text { during pregnancy }\end{array}$ & $\begin{array}{l}\text { RSV LRTI } \\
(41 \% \text { hospitalized) }\end{array}$ & $\begin{array}{l}\text { aOR, } 4.85(95 \% \mathrm{Cl}, 1.61-14.58) \\
P=0.005\end{array}$ & \multirow{6}{*}{$\begin{array}{l}\text { No significant bias concerns } \\
\text { affecting the relationship of ETS } \\
\text { and outcome }\end{array}$} \\
\hline & & $\begin{array}{l}\text { Parental smoking } \\
\text { in home }\end{array}$ & RSV LRTI & $\begin{array}{l}\text { NS aOR, } 0.81(95 \% \mathrm{Cl}, 0.19-3.37) \\
P=0.771\end{array}$ & \\
\hline & & $\begin{array}{l}\text { Maternal smoking } \\
\text { during pregnancy }\end{array}$ & $\begin{array}{l}\text { Hospital admission } \\
\text { (all cause; } 56 \% \text { of } \\
\text { admissions were RSV LRTI) }\end{array}$ & $\begin{array}{l}\text { NS aOR, } 1.19(95 \% \mathrm{Cl}, 0.20-7.07) \\
P=0.849\end{array}$ & \\
\hline & & $\begin{array}{l}\text { Parental smoking } \\
\text { in home }\end{array}$ & Hospital admission & $\begin{array}{l}\text { aOR, } 3.39(95 \% \mathrm{Cl}, 1.08-10.63) \\
P=0.003\end{array}$ & \\
\hline & & $\begin{array}{l}\text { Maternal smoking } \\
\text { during pregnancy }\end{array}$ & Length of hospital stay & NS, $P=0.150$ (OR not reported) & \\
\hline & & $\begin{array}{l}\text { Parental smoking } \\
\text { in home }\end{array}$ & Length of hospital stay & $P<0.001$ (OR not reported) & \\
\hline $\begin{array}{l}\text { Carbonell-Estrany } 2001 \\
\text { Spain [9] }\end{array}$ & $\begin{array}{l}\text { Prospective, } \\
\text { longitudinal study of } \\
999 \text { premature infants } \\
\text { (GA } \leq 32 \text { wks) }\end{array}$ & $\begin{array}{l}\text { Days of smoke } \\
\text { exposure }\end{array}$ & RSV hospitalization & $\mathrm{aOR}, 1.63(1.05-2.56) ; P=0.031$ & $\begin{array}{l}\text { No significant bias concerns } \\
\text { affecting the relationship of ETS } \\
\text { and outcome }\end{array}$ \\
\hline \multirow[t]{3}{*}{$\begin{array}{l}\text { Figueras-Aloy } 2008 \\
\text { Spain [20] }\end{array}$} & \multirow{3}{*}{$\begin{array}{l}\text { 2-cohort study of } \\
\text { premature infants } \\
\text { (GA 32-35 wks); } 202 \text { cases } \\
\text { hospitalized for RSV and } \\
5239 \text { controls not hospitalized } \\
\text { for respiratory illness }\end{array}$} & $\begin{array}{l}\text { Maternal smoking } \\
\text { during pregnancy }\end{array}$ & RSV hospitalization & $\begin{array}{l}\text { aOR, } 1.61(95 \% \mathrm{Cl}, 1.16-2.25) \\
P=0.004\end{array}$ & \multirow{3}{*}{$\begin{array}{l}\text { Authors note relatively high loss to } \\
\text { follow-up of } 12 \% \text { of children } \\
\text { fulfilling inclusion criteria. Both } \\
\text { ETS exposure variables were } \\
\text { significant in bivariate analysis at } \\
P<0.01 \text {, but when included in } \\
\text { multivariate model, only prenatal } \\
\text { smoking was significant, possibly } \\
\text { due to misclassification of ETS } \\
\text { exposure }\end{array}$} \\
\hline & & $\begin{array}{l}\leq 2 \text { smokers } \\
\text { in home }\end{array}$ & RSV hospitalization & NS in multivariate model & \\
\hline & & & & $\begin{array}{l}\text { Significant in bivariate analysis, } \\
\text { OR } 1.59(95 \% \mathrm{Cl}, 1.12-2.26) ; \\
P=0.01\end{array}$ & \\
\hline Law 2004 Canada [10] & $\begin{array}{l}\text { Prospective cohort study } \\
\text { of } 1832 \text { premature infants } \\
\text { (GA 33-35 wks) }\end{array}$ & $\begin{array}{l}\geq 2 \text { smokers } \\
\text { in household }\end{array}$ & RSV hospitalization & $\begin{array}{l}\mathrm{aOR}, 1.87(95 \% \mathrm{Cl}, 1.07-3.26) ; \\
P=0.027\end{array}$ & $\begin{array}{l}\text { No significant bias concerns } \\
\text { affecting the relationship of ETS } \\
\text { and outcome }\end{array}$ \\
\hline \multicolumn{6}{|c|}{ Case-control study in premature infants } \\
\hline \multirow[t]{5}{*}{$\begin{array}{l}\text { Figueras-Aloy } 2004 \\
\text { Spain [21] }\end{array}$} & \multirow{5}{*}{$\begin{array}{l}\text { Case-control study of } \\
\text { premature infants } \\
\text { (GA 33-35 wks); } 186 \text { cases } \\
\text { hospitalized for RSV; } 371 \\
\text { controls born at same } \\
\text { time as cases }\end{array}$} & $\begin{array}{l}\text { Maternal smoking } \\
\text { during pregnancy }\end{array}$ & RSV hospitalization & NS in multivariate model & \multirow{5}{*}{$\begin{array}{l}\text { No significant bias concerns } \\
\text { affecting the relationship of ETS } \\
\text { and outcome }\end{array}$} \\
\hline & & & & $\begin{array}{l}\text { Significant in bivariate analysis } \\
\mathrm{OR}, 1.62(95 \% \mathrm{Cl}, 1.08-2.42) \\
P=0.027\end{array}$ & \\
\hline & & $\begin{array}{l}\text { Maternal smoking } \\
\text { at home }\end{array}$ & RSV hospitalization & NS in bivariate model & \\
\hline & & & & $\begin{array}{l}\mathrm{OR}, 1.49(95 \% \mathrm{Cl}, 1.01-2.18) ; \\
P=0.055\end{array}$ & \\
\hline & & $\geq 2$ smokers at home & RSV hospitalization & NS in bivariate model & \\
\hline
\end{tabular}


Table 1 Studies Reporting Risk of Developing Serious RSV (Laboratory-Confirmed RSV; N=14) (Continued)

$\mathrm{OR}, 1.41(95 \% \mathrm{Cl}, 0.92-2.14)$

$P=0.146$

Prospective cohort studies in the general population

Holberg 1991 US [22] Prospective birth cohort study of 1179 healthy infants followed for 1 year

von Linstow 2008

Prospective birth cohort study of 217 children

followed for 1 year

Case-control studies in the general population

$\begin{array}{ll}\begin{array}{l}\text { Bulkow 2002 } \\ \text { US [12] }\end{array} & \begin{array}{l}\text { Case-control study of } \\ \text { Alaska native children } \\ \text { aged }<3 \text { years with 204 } \\ \text { cases and 338 controls }\end{array} \\ \text { Gurkan 2000 } & \begin{array}{l}\text { Case-control study of } \\ 28 \text { cases and 30 controls } \\ \text { Turkey [23] }\end{array} \\ & \text { aged 2-18 months }\end{array}$

Smoker in household

RSV hospitalization

NS in multivariate model

Significant in bivariate analysis, OR, $1.61 ; P \leq 0.018$

- Nonsmoking parents

- Only smoker mother

- Only smoker father

RSV bronchiolitis admitted to the ED Serum cotinine assessed during ED visit and

- Both parents smokers month later

Significant differences in cases vs. controls $(P<0.05)$

for all ETS exposure variables; however, only father smoker was more prevalent in the control than case group

Significant differences in cases vs. controls $(P<0.05)$ in cotinine levels for both parents smokers vs. both parents nonsmokers and for only mother smoker vs. both parents nonsmokers in the control group

\begin{tabular}{|c|c|c|c|}
\hline $\begin{array}{l}\text { Hall } 1984 \\
\text { US [24] }\end{array}$ & $\begin{array}{l}\text { Case-control study } \\
\text { of } 29 \text { cases and } 58 \text { controls } \\
\text { hospitalized with non } \\
\text { respiratory acute illness }\end{array}$ & Smoking in household & RSV hospitalization \\
\hline $\begin{array}{l}\text { Hayes } 1989 \\
\text { American Samoa [25] }\end{array}$ & $\begin{array}{l}\text { Case-control study of } \\
\text { children aged }<1 \text { year } \\
\text { ( } 20 \text { cases and } 15 \text { well controls) }\end{array}$ & $\begin{array}{l}\text { Smoker in } \\
\text { household }\end{array}$ & $\begin{array}{l}\text { RSV hospitalization } \\
\text { (53\% laboratory-confirmed) }\end{array}$ \\
\hline
\end{tabular}

Significant difference in smoking in household in cases $(76 \%)$ vs. controls (40\%) $(P<0.05)$

Significant difference in smoker in household in cases (92\%) vs. well controls (53\%) $(P=0.04)$

aOR, $1.56(95 \%$ Cl, 1.32-1.98)
No significant bias concerns affecting the relationship of ETS and outcome

No significant bias concerns affecting the relationship of ETS and outcome; to reduce problems with colinearity, only 1-2 variables from each group of covariates (e.g., social variables, smoking parameters) were included in the multivariate model.

Unclear risk of ETS exposure misclassification because of high prevalence of smoking and frequency of indoor visiting among households during winter RSV season; low risk of other types

No multivariate analysis

performed (confounding bias)

No multivariate analysis

performed (confounding bias)

No multivariate analysis

performed (confounding bias) $53 \%$ of hospitalizations were

laboratory-confirmed RSV 
Table 1 Studies Reporting Risk of Developing Serious RSV (Laboratory-Confirmed RSV; N=14) (Continued)

\begin{tabular}{|c|c|c|c|c|c|}
\hline & $\begin{array}{l}\text { aged }<2 \text { years and } 5 \text { controls } \\
\text { for each case }\end{array}$ & $\begin{array}{l}\text { from the Medical Birth } \\
\text { Register }\end{array}$ & & & $\begin{array}{l}\text { No significant bias concerns } \\
\text { affecting the relationship of ETS } \\
\text { and outcome }\end{array}$ \\
\hline $\begin{array}{l}\text { Reeve } 2006 \\
\text { Australia [11] }\end{array}$ & $\begin{array}{l}\text { Case-control study with } \\
271 \text { cases and } 542 \text { controls } \\
\text { (median age } 6 \mathrm{mo} \text { ) }\end{array}$ & Maternal smoking & RSV hospitalization & $\begin{array}{l}\text { NS in main multivariate } \\
\text { modelBivariate OR not } \\
\text { reported CART analysis } \\
\text { performed to define groups } \\
\text { that are most homogeneous } \\
\text { with regard to the outcome of } \\
\text { RSV hospitalization. CART } \\
\text { analysis found that smoking } \\
\text { was a risk factor in children } \\
\text { with birthweight }>2500 \mathrm{~g} \text { and } \\
\text { single mothers ( } 41.0 \% \text { hospitalized } \\
\text { vs. } 26.9 \% \text { for single nonsmoking } \\
\text { mothers)Smoking was not } \\
\text { significant for any other group }\end{array}$ & $\begin{array}{l}\text { Analysis was weakened by } \\
\text { reliance on a questionnaire that did } \\
\text { not seek to quantify ETS exposure } \\
\text { and by the absence of laboratory } \\
\text { confirmation of ETS exposure.63 } \\
\text { participants were excluded due to } \\
\text { data unavailability ( } 37 \text { of these } \\
\text { were missing the mother's } \\
\text { smoking status and } 47 \text { had proven } \\
\text { RSV), although the missing data } \\
\text { were not statistically significant }\end{array}$ \\
\hline $\begin{array}{l}\text { Stensballe } 2006 \\
\text { Denmark [26] }\end{array}$ & $\begin{array}{l}\text { Case-control study } \\
\text { of } 2564 \text { cases and } \\
12816 \text { controls from } \\
\text { birth to } 18 \text { months }\end{array}$ & $\begin{array}{l}\text { Any maternal smoking } \\
\text { during pregnancy and } \\
\text { lactation }\end{array}$ & RSV hospitalization & $\mathrm{aOR}, 1.35(95 \% \mathrm{Cl}, 1.20-1.52) ; P<0.001$ & $\begin{array}{l}\text { No significant bias concerns } \\
\text { affecting the relationship of ETS } \\
\text { and outcome }\end{array}$ \\
\hline
\end{tabular}

aOR = adjusted (multivariate) odds ratio; $\mathrm{BPD}=$ bronchopulmonary dysplasia (now chronic lung disease); $\mathrm{CART}=$ Classification and regression tree; $\mathrm{Cl}=$ confidence interval; $\mathrm{ED}=$ emergency department; $\mathrm{ETS}=$ environmental tobacco smoke; $\mathrm{OR}=$ odds ratio; $\mathrm{GA}=$ gestational age; $\mathrm{LRTI}=$ lower respiratory tract infection; $\mathrm{NS}=$ not significant; $\mathrm{RSV}=$ respiratory syncytial virus. 


\begin{tabular}{|c|c|c|c|c|c|}
\hline Study, Year, Country & Design and Population & Smoke Exposure & Outcome & Results & Bias Assessment \\
\hline \multicolumn{6}{|c|}{ Cohort study in premature infants } \\
\hline $\begin{array}{l}\text { Gavin } 2007 \\
\text { US [27] }\end{array}$ & $\begin{array}{l}\text { Retrospective cohort study } \\
\text { of } 2098 \text { premature infants } \\
\text { (GA 32-35 weeks) in the } \\
\text { Texas Medicaid program }\end{array}$ & $\begin{array}{l}\text { Maternal smoking } \\
\text { status during pregnancy } \\
\text { from the birth certificate }\end{array}$ & $\begin{array}{l}\text { Insurance claims for } \\
\text { bronchiolitis or RSV } \\
\text { hospitalization in } \\
\text { the first year of life }\end{array}$ & $\begin{array}{l}\text { NS, aOR, } 0.78 \\
(95 \% \mathrm{Cl}, 0.38-1.61)\end{array}$ & $\begin{array}{l}\text { Clinical diagnosis of RSV } \\
\text { leading to misclassification } \\
\text { could underestimate ETS } \\
\text { exposure risk }\end{array}$ \\
\hline \multicolumn{6}{|c|}{ Cohort studies in the general population } \\
\hline $\begin{array}{l}\text { Boyce } 2000 \\
\text { US [4] }\end{array}$ & $\begin{array}{l}\text { Retrospective cohort study } \\
\text { of children aged }<3 \text { years } \\
\text { in the Tennessee Medicaid } \\
\text { program from 1989-1993, } \\
\text { with } 248652 \text { child-years of } \\
\text { follow-up }\end{array}$ & $\begin{array}{l}\text { Maternal smoking } \\
\text { status during pregnancy } \\
\text { from the birth certificate }\end{array}$ & $\begin{array}{l}\text { Insurance claims for } \\
\text { bronchiolitis or RSV } \\
\text { hospitalization in } \\
\text { the first year of life }\end{array}$ & $\begin{array}{l}\text { aRR, } 1.3 \\
(95 \% \mathrm{Cl}, 1.2-1.4)\end{array}$ & $\begin{array}{l}\text { Clinical diagnosis of RSV } \\
\text { leading to misclassification } \\
\text { could underestimate ETS } \\
\text { exposure risk }\end{array}$ \\
\hline \multirow[t]{4}{*}{$\begin{array}{l}\text { Carroll } 2007 \\
\text { US [28] }\end{array}$} & $\begin{array}{l}\text { Retrospective cohort study } \\
\text { of } 101245 \text { term infants } \\
\text { enrolled in the Tennessee } \\
\text { Medicaid program }\end{array}$ & $\begin{array}{l}\text { Maternal smoking } \\
\text { status during pregnancy } \\
\text { from the birth certificate }\end{array}$ & $\begin{array}{l}\text { Insurance claims for } \\
\text { bronchiolitis or RSV } \\
\text { pneumonia in } \\
\text { the first year of life }\end{array}$ & $\begin{array}{l}\text { - Hospitalization aOR, } 1.28 \\
\text { (95\% Cl, 1.20-1.36) }\end{array}$ & $\begin{array}{l}\text { Clinical diagnosis of RSV } \\
\text { leading to misclassification } \\
\text { could underestimate ETS } \\
\text { exposure risk }\end{array}$ \\
\hline & & & & $\begin{array}{l}\text { - ED visit aOR, } 1.22 \\
(95 \% \mathrm{Cl}, 1.13-1.31)\end{array}$ & \\
\hline & & & & $\begin{array}{l}\text { - Clinic visit aOR, } 1.06 \\
(95 \% \mathrm{Cl}, 1.01-1.12)\end{array}$ & \\
\hline & & & & $\begin{array}{l}\text {-Bronchiolitis diagnosis aHR, } \\
1.14(95 \% \mathrm{Cl}, 1.10-1.18)\end{array}$ & \\
\hline \multirow[t]{3}{*}{$\begin{array}{l}\text { Koehoorn } 2008 \\
\text { Canada [29] }\end{array}$} & $\begin{array}{l}\text { Retrospective cohort study } \\
\text { of } 93058 \text { infants aged } \\
2-12 \text { months }\end{array}$ & $\begin{array}{l}\text { Maternal smoking } \\
\text { status during pregnancy } \\
\text { from perinatal database }\end{array}$ & $\begin{array}{l}\text { Diagnostic codes for } \\
\text { bronchiolitis for } \\
\text { outpatient visits or } \\
\text { hospitalizations }\end{array}$ & $\begin{array}{l}\text { - Inpatient onlyaHR, } 1.47 \\
(95 \% \mathrm{Cl}, 1.27-1.69)\end{array}$ & $\begin{array}{l}\text { Clinical diagnosis of } \\
\text { bronchiolitis leading to } \\
\text { misclassification could } \\
\text { underestimate ETS } \\
\text { exposure risk }\end{array}$ \\
\hline & & & & $\begin{array}{l}\text { - Outpatient or inpatient NS in } \\
\text { multivariate model, aHR, } 1.03 \\
\text { ( } 95 \% \mathrm{Cl}, 0.97-1.09)\end{array}$ & $\begin{array}{l}\text { Maternal smoking during } \\
\text { pregnancy was significant in } \\
\text { bivariate analysis for both } \\
\text { case definitions, but when } \\
\text { included in the multivariate } \\
\text { models, it was significantly } \\
\text { associated only with the } \\
\text { inpatient (more severe) case } \\
\text { definition }\end{array}$ \\
\hline & & & & $\begin{array}{l}\text { - Significant in bivariate analysis, } \\
\text { OR } 1.14(95 \% \mathrm{Cl}, 1.08-1.21) ; \\
\text { no } P \text { value reported }\end{array}$ & \\
\hline $\begin{array}{l}\text { Marbury } 1996 \\
\text { US [30] }\end{array}$ & $\begin{array}{l}\text { Prospective cohort study } \\
\text { of } 1424 \text { children with private } \\
\text { insurance followed to } \\
\text { age } 2 \text { years }\end{array}$ & $\begin{array}{l}\text { Maternal smoking } \\
\text { status }\end{array}$ & $\begin{array}{l}\text { Diagnosis of } \\
\text { bronchiolitis from } \\
\text { electronic medical } \\
\text { records }\end{array}$ & $\begin{array}{l}\text { NS, aRR, } 1.3(95 \% \mathrm{Cl}, 0.8-2.2) ; \\
\text { no } P \text { value reported }\end{array}$ & $\begin{array}{l}\text { Clinical diagnosis of } \\
\text { bronchiolitis leading to } \\
\text { misclassification could } \\
\text { underestimate ETS exposure } \\
\text { risk The authors noted that } \\
\text { smokers were less likely to }\end{array}$ \\
\hline
\end{tabular}




\begin{tabular}{|c|c|c|c|c|c|}
\hline \multirow[t]{2}{*}{$\begin{array}{l}\text { Reese et al., } 1992 \\
\text { Australia [18] }\end{array}$} & $\begin{array}{l}\text { Retrospective cohort study } \\
\text { of } 491 \text { patients up to } \\
\text { age } 17 \text { years admitted } \\
\text { to an Australian children's } \\
\text { hospital June-Dec. } 1987 \\
\text { for whom urinary cotinine } \\
\text { levels were available. }\end{array}$ & \multirow[t]{2}{*}{$\begin{array}{l}\text { Urinary cotinine level, } \\
\text { analyzed without knowledge } \\
\text { of exposure status } \\
\text { or diagnosis }\end{array}$} & \multirow[t]{2}{*}{$\begin{array}{l}\text { Hospitalization with } \\
\text { diagnosis of } \\
\text { bronchiolitis vs. a } \\
\text { non-respiratory } \\
\text { diagnosis (limited to } \\
\text { patients aged 5-15 } \\
\text { mos in the nonrespiratory } \\
\text { illness group) }\end{array}$} & \multirow[t]{2}{*}{$\begin{array}{l}\text { Elevated cotinine levels found in } \\
\text { bronchiolitis vs. nonrespiratory } \\
\text { illness group }(P<0.02) \\
\text { Subanalysis of the bronchiolitis } \\
\text { group by RSV status found no } \\
\text { significant difference between } \\
\text { RSV-positive }(n=16) \text { and } \\
\text { RSV-negative }(n=23) \text { patients; } \\
\text { both subgroups had elevated } \\
\text { cotinine vs. the nonrespiratory } \\
\text { illness group }\end{array}$} & \multirow[t]{2}{*}{$\begin{array}{l}\text { Risk of confounding not } \\
\text { clear; regression analysis } \\
\text { appears to have been } \\
\text { performed but was } \\
\text { insufficiently reported } \\
\text { (no aORs reported) }\end{array}$} \\
\hline & $\begin{array}{l}\text { Among those with } \\
\text { cotinine levels, } 41 \text { patients } \\
\text { (aged 5-15 mos.) were } \\
\text { diagnosed with bronchiolitis }\end{array}$ & & & & \\
\hline \multicolumn{6}{|c|}{ Case-control studies in the general population } \\
\hline $\begin{array}{l}\text { Holman } 2003 \\
\text { US [3] }\end{array}$ & $\begin{array}{l}\text { Case-control study of } \\
224 \text { infants aged }<1 \text { year } \\
\text { who died from bronchiolitis, } \\
\text { and } 2336 \text { controls }\end{array}$ & $\begin{array}{l}\text { Maternal smoking } \\
\text { status during pregnancy }\end{array}$ & $\begin{array}{l}\text { Bronchiolitis death from } \\
\text { death certificate data }\end{array}$ & $\mathrm{aOR}, 1.6(95 \% \mathrm{Cl}, 1.0-2.6)$ & $\begin{array}{l}\text { Clinical diagnosis of } \\
\text { bronchiolitis from death } \\
\text { certificate leading to } \\
\text { misclassification could } \\
\text { underestimate ETS } \\
\text { exposure risk }\end{array}$ \\
\hline \multirow[t]{4}{*}{$\begin{array}{l}\text { McConnochie } 1986 \\
\text { US [31] }\end{array}$} & \multirow{4}{*}{$\begin{array}{l}\text { Case-control study of } \\
53 \text { cases of bronchiolitis and } \\
106 \text { controls in children } \\
\text { aged }<2 \text { years presenting } \\
\text { to a physician's officeBivariate } \\
\text { analysis included } 3 \text { ETS } \\
\text { exposure variables, but only } \\
\text { "passive smoking" was } \\
\text { included in the multivariate } \\
\text { analysis }\end{array}$} & Any passive smoking & $\begin{array}{l}\text { Bronchiolitis from diagnostic } \\
\text { registry and record review }\end{array}$ & $\begin{array}{l}\text { aOR, } 3.87 \text { if no family history of } \\
\text { asthma (no Cl or } P \text { value } \\
\text { reported)aOR, } 4.03 \text { if family history } \\
\text { of asthma (no Cl or } P \text { value } \\
\text { reported) }\end{array}$ & \multirow{4}{*}{$\begin{array}{l}\text { Clinical diagnosis of } \\
\text { bronchiolitis leading to } \\
\text { misclassification could } \\
\text { underestimate ETS exposure } \\
\text { risk Interviews related to } \\
\text { smoking status were } \\
\text { conducted approximately } \\
7.8 \text { years after the } \\
\text { bronchiolitis episodes; } \\
\text { current and former smokers } \\
\text { at the time of the interview } \\
\text { were assumed to be smoking } \\
\text { at the time of the } \\
\text { bronchiolitis episode }\end{array}$} \\
\hline & & Smoking in household & Bronchiolitis & $\begin{array}{l}\text { Bivariate OR, } 3.21 \\
(95 \% \mathrm{Cl}, 1.42-7.25)\end{array}$ & \\
\hline & & Mother smokes & Bronchiolitis & $\begin{array}{l}\text { Bivariate OR, } 2.33 \\
(95 \% \mathrm{Cl}, 1.19-4.57)\end{array}$ & \\
\hline & & Father smokes & Bronchiolitis & $\begin{array}{l}\text { NS in bivariate model, OR } 1.71 \\
(95 \% \mathrm{Cl}, 0.87-3.33)\end{array}$ & \\
\hline
\end{tabular}

participate in the study (the ndoor Air and Children's

Health Study) and that

smokers who participate

may differ from those who

do not. They also noted the

do not. They also noted the

possibility of underreporting of smoking

Risk of confounding not regression analysis pears to have be performed but was

(nofficiently reported

diagnosis (limited to

ged $5-15$

mos in the nonrespiratory

cotinine vs. the nonrespiratory

mong those with

cotinine levels, 41 patients

(aged 5-15 mos.) were

Case-control studies in the general population

aHR = adjusted hazard ratio; $\mathrm{aOR}=$ adjusted (multivariate) odds ratio; $\mathrm{aRR}=$ adjusted rate ratio $\mathrm{Cl}=$ confidence interval; $\mathrm{ED}=$ emergency department; $\mathrm{ETS}=$ environmental tobacco smoke; $\mathrm{GA}=$ gestational age; $\mathrm{LRTI}=$ lower respiratory tract infection; NS = not significant; $\mathrm{RSV}=$ respiratory syncytial virus; $\mathrm{OR}=$ odds ratio. 
Table 3 Studies examining disease severity $(\mathbf{N}=\mathbf{8})$

\section{Study, Year, Country Design and Population}

Groothuis et al., $1988 \quad$ Prospective cohort study Smokers in home US [32]

aged $<2$

receiving home oxygen therapy;

participants followed for 5 mos

(Dec-Apr)

Risk of hospitalization among children in the general population with RSV illness
Al-Shehri $2005 \quad$ Case-control study; History of exposur

51 children aged $\leq 5$ years

hospitalized for bronchiolitis

to smoking

with bronchiolitis but not

hospitalized (controls);

$40 \%$ of cases were RSV

Hall 2009 US [2]

919 children aged $<5$

RSV infections

household

Mother smokes

Prospective study of 195 infants

(mean age 3.8 months) with

laboratory-confirmed

RSV infection

Exposure to smoke

from at least one

family member

Canada [34]

Disease severity in children in the general population hospitalized with RSV illness
Al-Sonboli $2006 \quad$ Prospective study of $325 \quad$ Smoking in

$\begin{array}{lll}\text { Al-Sonboli } 2006 & \begin{array}{l}\text { Prospective study of } 325 \\ \text { children aged } \leq 2 \text { with }\end{array} & \begin{array}{l}\text { Smoking in } \\ \text { Yemen [35] }\end{array} \\ & \text { household }\end{array}$

seeking emergency or

hospital (82\% RSV)

Bradley 2005
US [36]

Prospective evaluation of

206 infants hospitalized

with their first episode of

Chatzimichael 2007

240 children aged

6-24 months hospitalized

for bronchiolitis

Current materna

smokingMaterna

smoking status

during pregnancy

Exposure to $>5$

cigarettes per day in

the home; children

with prenatal exposure

were excluded

Sritippayawan 2006

Study of 19 children

(median age 9 months)

Exposure measured

by urinary cotinine outpatient services at

severe RSV bronchiolitis

Prospective study of
Outcome

Results

Bias Assessment

Risk of hospitalization

(11 of 16 with RSV hospitalized)

vs. outpatient treatment

Risk of hospitalization vs. outpatient treatment for bronchiolitis

Risk of hospitalization vs.
Lowest oxygen

saturation rate

Disease severity measured with a clinical rating tool that included hypoxemia
$2.51(95 \% \mathrm{Cl}, 2.11-3.73)$ outpatient treatment

Risk of hospitalization vs. outpatient treatment

Hospitalization (113) vs. outpatient treatment (82) of RSV

Severe hypoxia among RSV-positive group

NS in multivariate analysi (no aOR, $\mathrm{Cl}$, or $\mathrm{P}$ value)NS in bivariate analysis $(P=0.43)$

Not included in multivariate analysis NS in bivariate analysis $(P=0.21)$

ETS exposure was unrelated

to hospitalization

( $P$ value not reported)

aOR, $3.8(95 \% \mathrm{Cl}, 1.5-9.8)$ $P=0.002$

Hypoxemia (oxygen

saturation $<92 \%$ )

Current maternal smoking was pregnancy only $(n=10)$
NS: bivariate analysis reported

and $P$ value not given

$P=0.05$

No multivariate analysis performed (confounding bias)

Risk of participant selection bias because both cases and controls had bronchiolitis

No significant bias concerns affecting the relationship of ETS and outcome

No multivariate analysis performed (confounding bias)

No description of how smoke exposure or other family characteristics were ascertained (exposure bias) associated with lower oxygen saturation $P=0.05 \mathrm{No}$ effect of smoking during

No significant bias concerns affecting the relationship of ETS and outcome

aOR, $2.2(95 \% \mathrm{Cl}, 1.1-3.6) ; P=0.003$ 
Table 3 Studies examining disease severity $(\mathbf{N}=\mathbf{8})$ (Continued)

\begin{tabular}{|c|c|c|}
\hline $\begin{array}{l}\text { admitted to the hospital } \\
\text { with laboratory-confirmed RSV LRTI }\end{array}$ & $\begin{array}{l}\text { Cotinine was detected in } 100 \% \text { of } \\
\text { infants with hypoxia vs. } 33 \% \text { of those } \\
\text { without hypoxia; } P=0.01\end{array}$ & $\begin{array}{l}\text { confounding not clear; } \\
\text { regression analysis appears } \\
\text { to have been performed but } \\
\text { was insufficiently reported } \\
\text { so it was not possible to tell } \\
\text { which factors were } \\
\text { controlled for }\end{array}$ \\
\hline
\end{tabular}

$\mathrm{aOR}=$ adjusted (multivariate) odds ratio; $\mathrm{BPD}=$ bronchopulmonary dysplasia; $\mathrm{Cl}=$ confidence interval; $\mathrm{ETS}=$ environmental tobacco smoke; $\mathrm{LRTI}=$ lower respiratory tract infection; $\mathrm{NS}=$ not significant; $\mathrm{RSV}=$ respiratory syncytial virus. 
conflicting associations with three different outcomes: RSV LRTI, all-cause hospital admission, and length of hospital stay [19]. Measures of smoke exposure in the home and maternal smoking gave conflicting results when evaluated in 2 studies $[6,20]$, including a study in premature infants [20]. Finally, a small case-control study in a general population in Turkey found that several exposure variables (only mother smoking, both parents smoking, any parent smoking, and serum cotinine) were associated with significant increase in risk of admittance to the ED; however, only father smoking was significantly associated with a decrease in risk [23].

Of the studies of laboratory-confirmed RSV hospitalization described in Table 1, 5 were conducted in premature infants and 9 were conducted in general populations. All 5 studies of laboratory-confirmed RSV in premature infants found increased risk related to ETS exposure in either bivariate or multivariate analyses [9,10,19-21] (Table 1). The 2004 case-control study of infants with a gestational age of 33 to 35 weeks by Figueras-Aloy et al. [21] found an OR of 1.62 in the bivariate analysis that did not remain significant in the multivariate analysis. However, the same researchers published a much larger cohort study in 2008, in a premature population with a gestational age of 32 to 35 weeks, reporting a nearly identical aOR (1.61) for maternal smoking that remained significant in the multivariate analysis [20]. The authors of the 2004 study note that the prevalence of ETS exposure decreased in Spain during the years before the study (52\% during the 1999 2000 RSV season compared with $30 \%$ in this study) because of anti-smoking campaigns or health education [21]. The significant association in the larger study suggests that the earlier study was underpowered for the multivariate analysis.

Of the 9 studies of laboratory-confirmed RSV illness in general populations described in Tables 1,2 were prospective cohort studies and 7 were case-control studies (Table 1). Risk of RSV LRTI in an outpatient office setting [22] and risk of RSV hospitalization from ETS exposure (smoking in the household, but not from maternal smoking during pregnancy) [6] were not significant in the cohort studies.

The 7 case-control studies of laboratory confirmed RSV illness in general populations ranged in size from 20 to 2,564 cases (Table 1), and all found a significant association between ETS exposure and risk of RSV hospitalization in either the multivariate or bivariate analyses, with the ORs from the 4 largest studies clustering tightly between 1.35 and 1.6. The 3 smallest casecontrol studies included in Table 1 did not provide ORs but compared ETS exposure prevalence between the cases and healthy controls [23-25]. All 3 found significant differences in ETS exposure in cases versus controls. The Turkish study also demonstrated significantly higher cotinine levels in serum samples from cases than from healthy controls [23]. In a case-control study of Alaska native children, risk was apparent in the bivariate analysis, but not in the multivariate analyses [12] (Table 1). The authors noted that misclassification of exposure status may have been a problem. The study was conducted in Alaska, where children spend much time indoors during the winter RSV season and could be exposed to ETS when visiting other houses or community buildings. This appears likely, because there were smokers living in the households of $59 \%$ of the controls and $68 \%$ of the cases. The consistency of findings associating ETS exposure and increased risk of serious RSV, coupled with the inconsistency of the variables associated with these significant results, highlights the challenges of assessing and categorizing ETS exposure.

\section{ETS exposure and clinically diagnosed RSV disease}

As with the studies in Table 1, the studies in Table 2 seek to answer the question, does ETS exposure increase the risk that an uninfected child will develop serious RSV? In these studies, however, the RSV diagnosis was based on clinical findings rather than a laboratory test. Table 2 presents 8 studies, 6 of which reported a significant association between ETS exposure and bronchiolitis hospitalization or outpatient treatment. Because other organisms may cause bronchiolitis, there may be possible misclassification of RSV disease status [33].

The large general population cohort studies including bronchiolitis hospitalization as an outcome by Boyce et al. [4], Carroll et al. [28], and Koehoorn et al. [29] are in agreement with the 12 studies in Table 1 that identified an increased risk of RSV hospitalization associated with ETS exposure. Carroll and colleagues also demonstrated increased risk of ED visit or clinic visit for bronchiolitis and bronchiolitis diagnosis related to ETS exposure [28].

In other studies assessing risk of bronchiolitis LRTI in children presenting in the office setting, 2 studies found an increased risk for at least one ETS variable [28,31], whereas 2 other studies did not [29,30]. Of these, the positive study by Carroll et al. [28] had the greatest statistical power.

Only the Holman study assessed risk of death from bronchiolitis; the risk was increased by maternal smoking $(\mathrm{aOR}, 1.6)$ [3].

\section{ETS exposure and severity of RSV illness}

The 8 studies in Table 3 address the question, given that a child has contracted RSV, does ETS exposure increase the severity of illness? Four studies compared ETS exposure in children hospitalized for RSV and children with RSV who were not hospitalized. Three of these 
studies, including a small study of premature infants with BPD, found no effect of ETS exposure on the likelihood of hospitalization for RSV [2,32,34]. One small study found an effect of ETS exposure, but only $40 \%$ of the hospitalized children were found to have RSV infections, with the remaining $60 \%$ representing bronchiolitis caused by other viruses [33].

Four studies examined clinical severity (degree of hypoxemia) of RSV LRTIs among children hospitalized for treatment. All 4 found that ETS exposure was associated with more severe illness (Table 3). Bradley et al. found that hypoxemia was associated with postnatal but not prenatal smoke exposure [36]. Chatzimichael et al. found that breastfeeding was protective against the effect of ETS exposure on disease severity [37]. Based on a small number of studies of RSV severity, ETS exposure does not appear to increase the risk of hospitalization versus outpatient treatment among children infected with RSV, but hospitalized RSV patients exposed to ETS have more severe disease.

\section{Summary of potential bias in observational studies of ETS exposure and serious RSV disease}

As the studies reviewed were observational, we evaluated the primary sources of bias that could potentially affect the estimates of association with ETS exposure (Additional file 2). We found that 21 of the 30 studies confirmed the RSV diagnosis through laboratory testing for RSV or multiple respiratory illnesses including RSV in all of the study populations [2,5,6,9-12,19-26,32-36,38]. The remaining studies had a risk of disease misclassification bias of RSV because diagnostic codes (primarily for bronchiolitis) or diagnoses from medical records were used [3,4,27-31,37,39]. Misclassification of RSV disease may attenuate the association of ETS exposure and severe RSV disease, and the studies of clinically diagnosed RSV patients may provide conservative estimates of ETS exposure risk.

Overall, we identified few studies that had potential selective reporting bias, confounding bias, exposure ascertainment bias for ETS, or participant selection bias. Selective outcome reporting was a potential problem in 2 studies [38,39], meaning that outcomes were not described sufficiently to determine which factors were included and potentially controlled for in the analysis. Although confounding is a threat across observational studies (because it is difficult to control for both measureable and unmeasurable factors), multivariate analyses were not conducted in a number of studies [23-25,32,34,38], which could lead to an overestimate of the effect of ETS exposure. One study had a high risk of participant selection bias, where both cases and controls were diagnosed with bronchiolitis [33]. Only 2 studies had an unclear risk of ETS exposure [12,35]. Al-Sonboli and colleagues
[35] did not describe how the ETS exposure data or other demographic data were obtained. In the Bulkow et al study, ETS exposure was highly prevalent in the community (in both cases and controls) and indoor visiting was frequent during the winter RSV season [12]; therefore, the ETS exposure variable "smoker in household" was not an adequate proxy for exposure in this population.

No statistical analysis of the risk of bias across studies was performed for this review.

\section{Discussion}

The impact of ETS exposure on RSV disease in infants and young children is consistent among studies using laboratory confirmation of RSV infection and clinical diagnosis of bronchiolitis or RSV. Among 14 populationbased studies that examined the risk of admission to the hospital or ED for RSV disease, 12 showed that at least one type of ETS exposure in each study was associated with a significant adverse outcome in the bivariate or multivariate analysis. The observation that ETS exposure increases the risk that a child will develop RSV disease that will require hospitalization is robust because these studies used different methods (prospective, retrospective, cohort, case-control) in different patient populations (infants who were premature, term, or with compromising conditions), in a variety of countries and cultures. In addition, the evidence suggests that ETS exposure is associated with more severe hypoxia among children hospitalized for RSV [35-38], and one study found an increased risk of mortality from bronchiolitis [3].

Among studies in premature infants, 5 [9,10,19-21] of $7[9,10,19-21,27,32]$ found ETS exposure to be a significant risk factor in bivariate or multivariate analysis, including 5 of the $6[9,10,19-21,32]$ studies assessing laboratory-confirmed RSV. One study contradicting this conclusion did not have laboratory confirmation of the diagnosis and relied on a claims database, rather than direct data collection, for ascertainment of the ETS exposure status [27]. Misclassification of disease status or missed diagnosis may have contributed to the negative findings in this study. The other was a small study of 30 premature infants with BPD on home oxygen therapy, 16 of whom developed RSV [32].

The evidence concerning whether ETS exposure increases the risk of mild RSV infection is much less convincing. In a very large study, Carroll et al. found ETS exposure to be associated with only a small increased risk of RSV illness (OR, 1.06) presenting in the outpatient setting [28]. If this OR represents the true risk, the Holberg [22] and Marbury [30] studies, which did not find a risk, would have been underpowered to detect it because of smaller sample sizes. Because nearly 
all children contract RSV during the first few years of life [1] and most cases are mild [2], there may be a ceiling effect. If children with no ETS exposure are almost certain to contract RSV, ETS exposure can increase the risk of mild infection only slightly.

Misclassification of ETS exposure is a major challenge in studying associations of ETS exposure with disease. Misclassification of exposure status produces a bias in the direction of reducing the apparent magnitude of the risk, leading to either an underestimate of the true ETS exposure risk or to a null finding. Misclassification of an infant or child's ETS exposure comes from researchers' use of one or a few measures of possible exposure, which actually can come through many avenues. Examples include in utero exposure through active and passive maternal smoking and postnatal smoking by the mother, father, other individuals living in the home, visitors, and babysitters. ETS exposure outside the home occurs in public places, day care settings, and houses of friends and relatives. No study in this review gathered exposure data for all potential sources. The smoking status of, for example, the parent is a poor proxy for this global exposure as demonstrated by cotinine level studies. Urinary or serum cotinine (a metabolite of nicotine) is an objective measure of ETS exposure but provides information regarding only the previous 48 to 72 hours of exposure [40]. In one study, infants whose parents reported that they did not smoke had mean cotinine levels that were $80 \%$ as high as those for infants with one smoking parent [39]. Some infants of nonsmoking parents had higher cotinine levels than some infants with two smoking parents [39].

Confounding bias is another potential obstacle to determining the association between ETS exposure and serious RSV disease. A few studies found an ETS exposure effect in bivariate analyses but not in multivariate analyses after adjustment for other factors [11,21,39]. Multivariate models that include ETS exposure and its related factors may be difficult to interpret due to potential collinearity. Smoking status has a well-known association with socioeconomic status (SES) [41], and SES is predictive of ETS exposure in children [42]. Therefore, SES may be a proxy for global ETS exposure over the early years of life. In addition to SES, smoking status is also predicted by race, educational attainment, and marital status [43]. Few of the multivariate studies provided a rationale for their selection of control variables. In reporting of future studies, greater details about the multivariate modeling steps may aid in assessment of collinearity when significant bivariate outcomes become nonsignificant in multivariate analysis.

This review has several limitations. The search was limited to studies published from 1990 to April 2009 in the English language. We searched only Pubmed and
Embase and did not attempt to locate unpublished studies. The nature of the primary studies precluded a metaanalysis. The large retrospective database analyses included in this study (Table 2) all depended on bronchiolitis or RSV disease classification from diagnostic codes or medical record diagnosis. Although RSV is a leading cause of LRTI in infants and children, identifying the etiology of LRTI is not systematically undertaken in EDs or physician offices. Methods and reporting of ETS exposure ascertainment in these studies also varies widely. However, in most studies, data on the child's ETS exposure level ultimately are gathered from parent or caregiver report, whether through direct data collection for the study or, for example, through retrospective review of the mother's prenatal health records. Our review highlights the inherent difficulty of accurately assessing global ETS exposure.

\section{Conclusion}

Overall we found ample evidence that ETS exposure places infants and young children at increased risk of hospitalization for RSV-attributable LRTIs, and increases the severity of illness as measured by degree of hypoxia among children hospitalized for RSV. Based on a small number of studies, we also found evidence that ETS exposure does not increase the likelihood among general populations with RSV of hospitalization versus outpatient treatment.

The prevention of serious RSV illness provides one more rationale for protecting infants and young children from exposure to tobacco smoke, especially high-risk groups such as premature infants and those with chronic conditions who are considered at increased risk of serious RSV disease.

\section{Additional files}

Additional file 1: Table S1. Provides full bias assessment of studies reported in this systematic literature review.

Additional file 2: PRISMA Checklist. Provides location in manuscript where PRISMA topics are reported.

\section{Competing interests}

This project was funded under a contract with Medlmmune, LLC. Joseph R. DiFranza, MD, provided consultant services to Medlmmune. Amy M. Barrett, MSPH, MA, and Ann D. Colosia, PhD, are employees of RTI Health Solutions and provided consulting services to Medlmmune. Parthiv J. Mahadevia, MD, $\mathrm{MPH}$, and Anthony Masaquel, PhD, MPH, are employees of Medlmmune. All authors agreed on the final text and conclusions of the manuscript. There are no other competing interest disclosures.

\section{Acknowledgements}

Editorial assistance was provided by Susan DeRocco, PhD, and Gerard P. Johnson, PhD, of Complete Healthcare Communications, Inc. (Chadds Ford, PA) and was funded by Medlmmune. 


\section{Author details}

${ }^{1}$ Department of Family Medicine and Community Health, University of Massachusetts Medical School, 55 Lake Avenue North, Worcester, MA 01655 USA. ${ }^{2}$ Medlmmune, Health Outcomes \& Pharmacoeconomics, One Medlmmune Way, Gaithersburg, MD 20878, USA. ${ }^{3}$ RTI Health Solutions, 3040 Cornwallis Road, P.O. Box 12194, Research Triangle Park, NC 27709-2194, USA.

\section{Authors' contributions}

JD participated in the conception of the literature review and paper, reviewed published studies, analyzed data, and drafted portions of the manuscript. AM participated in the conception of the literature review and paper, reviewed studies, analyzed data, and critically revised the manuscript for important intellectual content. $A B$ and $A C$ each participated in the design and conception of the literature review and paper, reviewed published studies, extracted and analyzed data, and drafted portions of the manuscript. PM participated in the conception of the manuscript, analyzed data, and critically revised the manuscript for important intellectual content. All authors read and approved the final manuscript.

Received: 21 September 2011 Accepted: 21 June 2012

Published: 21 June 2012

\section{References}

1. Hall CB: Textbook of Pediatric Infectious Diseases. 4th edition. Philadelphia, PA: WB Saunders; 1998:2084-2110.

2. Hall CB, Weinberg GA, Iwane MK, Blumkin AK, Edwards KM, Staat MA, Auinger P, Griffin MR, Poehling KA, Erdman D, et al: The burden of respiratory syncytial virus infection in young children. N Engl J Med 2009, 360(6):588-598.

3. Holman RC, Shay DK, Curns AT, Lingappa JR, Anderson LJ: Risk factors for bronchiolitis-associated deaths among infants in the United States. Pediatr Infect Dis J 2003, 22(6):483-490.

4. Boyce TG, Mellen BG, Mitchel EF Jr, Wright PF, Griffin MR: Rates of hospitalization for respiratory syncytial virus infection among children in Medicaid. J Pediatr 2000, 137(6):865-870.

5. Nielsen HE, Siersma V, Andersen S, Gahrn-Hansen B, Mordhorst CH, Norgaard-Pedersen B, Roder B, Sorensen TL, Temme R, Vestergaard BF: Respiratory syncytial virus infection-risk factors for hospital admission: a case-control study. Acta Paediatr 2003, 92(11):1314-1321.

6. von Linstow ML, Hogh M, Nordbo SA, Eugen-Olsen J, Koch A, Hogh B: A community study of clinical traits and risk factors for human metapneumovirus and respiratory syncytial virus infection during the first year of life. Eur J Pediatr 2008, 167(10):1125-1133.

7. Nafstad P, Jaakkola JJ, Hagen JA, Botten G, Kongerud J: Breastfeeding, maternal smoking and lower respiratory tract infections. Eur Respir J 1996, 9(12):2623-2629.

8. Carbonell-Estrany X, Quero J, Bustos G, Cotero A, Domenech E, FiguerasAloy J, Fraga JM, Garcia LG, Garcia-Alix A, Del Rio MG, et al: Rehospitalization because of respiratory syncytial virus infection in premature infants younger than 33 weeks of gestation: a prospective study. IRIS Study Group. Pediatr Infect Dis J 2000, 19(7):592-597.

9. Carbonell-Estrany X, Quero J: Hospitalization rates for respiratory syncytial virus infection in premature infants born during two consecutive seasons. Pediatr Infect Dis J 2001, 20(9):874-879.

10. Law BJ, Langley JM, Allen U, Paes B, Lee DS, Mitchell I, Sampalis J, Walti H, Robinson J, O'Brien K, et al: The Pediatric Investigators Collaborative Network on Infections in Canada study of predictors of hospitalization for respiratory syncytial virus infection for infants born at 33 through 35 completed weeks of gestation. Pediatr Infect Dis J 2004, 23(9):806-814.

11. Reeve CA, Whitehall JS, Buettner PG, Norton R, Reeve DM, Francis F: Predicting respiratory syncytial virus hospitalisation in Australian children. J Paediatr Child Health 2006, 42(5):248-252.

12. Bulkow LR, Singleton RJ, Karron RA, Harrison LH, Alaska RSVSG: Risk factors for severe respiratory syncytial virus infection among Alaska native children. Pediatrics 2002, 109(2):210-216.

13. Office of Health and Environmental Assessment: Respiratory health effects of passive smoking: lung cancer and other disorders (EPA/600/6-90/ 006F). In. Edited by US Environmental Protection Agency. Washington, DC: US Environmental Protection Agency; 1992.
14. Committee on Infectious Diseases: From the American Academy of Pediatrics: Policy statements-Modified recommendations for use of palivizumab for prevention of respiratory syncytial virus infections. Pediatrics 2009, 124(6):1694-1701.

15. Moher D, Liberati A, Tetzlaff J, Altman DG: Preferred reporting items for systematic reviews and meta-analyses: the PRISMA statement. PLoS Med 2009, 6(7):e1000097.

16. The Cochrane Collaboration's tool for assessing risk of bias. http://www. ohg.cochrane.org/forms/Risk\%20of\%20bias\%20assessment\%20tool.pdf.

17. The IMpact-RSV Study Group: Palivizumab, a humanized respiratory syncytial virus monoclonal antibody, reduces hospitalization from respiratory syncytial virus infection in high-risk infants. Pediatrics 1998 102(3 Pt 1):531-537.

18. Horn SD, Smout RJ: Effect of prematurity on respiratory syncytial virus hospital resource use and outcomes. J Pediatr 2003, 143(5 suppl):S133-S141.

19. Broughton S, Roberts A, Fox G, Pollina E, Zuckerman M, Chaudhry S, Greenough A: Prospective study of healthcare utilisation and respiratory morbidity due to RSV infection in prematurely born infants. Thorax 2005, 60(12):1039-1044.

20. Figueras-Aloy J, Carbonell-Estrany X, Quero-Jimenez J, Fernandez-Colomer B, Guzman-Cabanas J, Echaniz-Urcelay I, Domenech-Martinez E: FLIP-2 Study: risk factors linked to respiratory syncytial virus infection requiring hospitalization in premature infants born in Spain at a gestational age of 32 to 35 weeks. Pediatr Infect Dis J 2008, 27(9):788-793.

21. Figueras-Aloy J, Carbonell-Estrany X, Quero J: Case-control study of the risk factors linked to respiratory syncytial virus infection requiring hospitalization in premature infants born at a gestational age of 33-35 weeks in Spain. Pediatr Infect Dis J 2004, 23(9):815-820.

22. Holberg CJ, Wright AL, Martinez FD, Ray CG, Taussig LM, Lebowitz MD: Risk factors for respiratory syncytial virus-associated lower respiratory illnesses in the first year of life. Am J Epidemiol 1991, 133(11):1135-1151.

23. Gurkan F, Kiral A, Dagli E, Karakoc F: The effect of passive smoking on the development of respiratory syncytial virus bronchiolitis. Eur J Epidemio/ 2000, 16(5):465-468.

24. Hall CB, Hall WJ, Gala CL, MaGill FB, Leddy JP: Long-term prospective study in children after respiratory syncytial virus infection. J Pediatr 1984, 105(3):358-364.

25. Hayes EB, Hurwitz ES, Schonberger LB, Anderson LJ: Respiratory syncytial virus outbreak on American Samoa. Evaluation of risk factors. Am J Dis Child 1989, 143(3):316-321.

26. Stensballe LG, Kristensen $K$, Simoes EA, Jensen $H$, Nielsen J, Benn CS, Aaby P: Atopic disposition, wheezing, and subsequent respiratory syncytial virus hospitalization in Danish children younger than 18 months: a nested case-control study. Pediatrics 2006, 118(5): e1360-e1368.

27. Gavin NI, Leader S: Predictive accuracy of risk factors for RSV-related hospitalizations among infants in low-income families born at 32 to 35 weeks of gestation. J Clin Outcomes Manag 2007, 14(6):323-331.

28. Carroll KN, Gebretsadik T, Griffin MR, Dupont WD, Mitchel EF, Wu P, Enriquez R, Hartert TV: Maternal asthma and maternal smoking are associated with increased risk of bronchiolitis during infancy. Pediatrics 2007, 119(6):1104-1112.

29. Koehoorn M, Karr CJ, Demers PA, Lencar C, Tamburic L, Brauer M: Descriptive epidemiological features of bronchiolitis in a populationbased cohort. Pediatrics 2008, 122(6):1196-1203.

30. Marbury MC, Maldonado G, Waller L: The indoor air and children's health study: methods and incidence rates. Epidemiology 1996, 7(2):166-174.

31. McConnochie KM, Roghmann KJ: Parental smoking, presence of older siblings, and family history of asthma increase risk of bronchiolitis. Am J Dis Child 1986, 140(8):806-812.

32. Groothuis JR, Gutierrez KM, Lauer BA: Respiratory syncytial virus infection in children with bronchopulmonary dysplasia. Pediatrics 1988, 82(2):199-203.

33. Al-Shehri MA, Sadeq A, Quli K: Bronchiolitis in Abha, Southwest Saudi Arabia: viral etiology and predictors for hospital admission. West Afr J Med 2005, 24(4):299-304.

34. Somech R, Tal G, Gilad E, Mandelberg A, Tal A, Dalal I: Epidemiologic, socioeconomic, and clinical factors associated with severity of respiratory syncytial virus infection in previously healthy infants. Clin Pediatr (Phila) 2006, 45(7):621-627. 
35. Al-Sonboli N, Hart CA, Al-Aghbari N, Al-Ansi A, Ashoor O, Cuevas LE: Human metapneumovirus and respiratory syncytial virus disease in children, Yemen. Emerg Infect Dis 2006, 12(9):1437-1439.

36. Bradley JP, Bacharier LB, Bonfiglio J, Schechtman KB, Strunk R, Storch G, Castro M: Severity of respiratory syncytial virus bronchiolitis is affected by cigarette smoke exposure and atopy. Pediatrics 2005, 115(1):e7-e14.

37. Chatzimichael A, Tsalkidis A, Cassimos D, Gardikis S, Tripsianis G, Deftereos S, Ktenidou-Kartali S, Tsanakas I: The role of breastfeeding and passive smoking on the development of severe bronchiolitis in infants. Minerva Pediatr 2007, 59(3):199-206.

38. Sritippayawan S, Prapphal N, Wong P, Tosukhowong P, Samransamruajkit R, Deerojanawong J: Environmental tobacco smoke exposure and respiratory syncytial virus infection in young children hospitalized with acute lower respiratory tract infection. J Med Assoc Thai 2006, 89(12):2097-2103.

39. Reese AC, James IR, Landau LI, Lesouef PN: Relationship between urinary cotinine level and diagnosis in children admitted to hospital. Am Rev Respir Dis 1992, 146(1):66-70.

40. Benowitz NL, Jacob P 3rd: Nicotine and cotinine elimination pharmacokinetics in smokers and nonsmokers. Clin Pharmacol Ther 1993, 53(3):316-323.

41. Tobacco use among U.S. racial/ethnic minority groups-African Americans, American Indians and Alaska Natives, Asian Americans and Pacific Islanders, Hispanics. A Report of the Surgeon General. Executive summary. MMWR Recomm Rep 1998, 47(RR-18):V-XV. 1-16.

42. Windham GC, Swan SH, Fenster L: Parental cigarette smoking and the risk of spontaneous abortion. Am J Epidemiol 1992, 135(12):1394-1403.

43. Office of the Surgeon General: The health consequences of smoking: a report of the Surgeon General. In. Edited by Services UDoHaH. Washington, DC: US Department of Health and Human Services; 2004.

doi:10.1186/1471-2431-12-81

Cite this article as: Difranza et al: Systematic literature review assessing tobacco smoke exposure as a risk factor for serious respiratory syncytial virus disease among infants and young children. BMC Pediatrics 2012 12:81.

\section{Submit your next manuscript to BioMed Central and take full advantage of:}

- Convenient online submission

- Thorough peer review

- No space constraints or color figure charges

- Immediate publication on acceptance

- Inclusion in PubMed, CAS, Scopus and Google Scholar

- Research which is freely available for redistribution 